Dr. Hueppe, in a recent work, has undertaken to find a common ground on which the two theories may meet. His conception is that the cholera bacillus may, like most pathogenic bacteria, exist in the saprophy tic
state. Frankel has demonstrated that it finds in the superficial layers of soil the necessary conditions of tion and the rivalry of other species. It leaves the soil not matured, as Pettenkofer claims, but virorous and capable of resisting the action of the
wastric juice when, by deglutition of saliva, respira ion, drinking water, or alimentary substances. it has reached the stomach. It develops in the intestinal organism it ceases to be infectious, and recovers its virulence by contact with the air or in the soil. If air and oxygen are deficient, the germ perishes. If both are
present in small quantities, it can lead an aerobic existence at the expense of the materials it encounters.

GOLD AS A THERAPEUTIC AGENT. By C. J. S. Thompson.

THE use of gold as a medicinal agent is of considerable antiquity, dating back to a very early period, it was accounted of great value by the alchemists of old. credited with wonderful healing properties, and the
diamond, the sapphire, ruby, and amethyst were supdiamond, the sapphire, ruby, and amethyst were sup-
posed to have marvelous virtues. The apothecaries of the seventeenth century used it largely as a stimulant, also in the treatinent of epilepsy, and it entered as an ingredient into many of their compound elixirs
and other preparations.
Culpeper, in his Physician, says: "Gold is temperate in gravity. It wonderf ully strengthens the heart and ings and swoonings, also fevers and falling sickness, and animal spirit."

For gold is cordial, and that's the reason

Down to the very early part of this century it wa included in most of the pharmacopoias of Europe, and other expensive rewedies once frequently employed in medical practice, the internal administration of use. easily be tested, and it is also stated to have dia-
phoretic properties. It was frequently used by mephoretic properties. It was frequently used by me-
dical wen fifty years ago in the treatment of syphilis.
inany of whom believed it superior to mercury in severe cases.
One of the oldest preparations of gold was known as crocus solis, and prepared in several ways. The cro-
cus solis of Germany was directed to be made by first cus solis of Germany was directed to be made by first weight of sulphur. It was then heated in a crucible till the mercury and sulphur became dissipated, and
the gold remained in the form of a brown powder. Another method of preparation, also, was by precipi$\mathrm{R}$ Divided gold

Acid. nitro-hydrochlor

To dissolve the metal, dilute the acid solution with twelve parts of water, then add a solution of potash
to excess. Wash and dry the precipitate thrown down. preparation of gold was by rubbing it into the gum
or over the tongue. Crocus solis formed the base of several preparations ed with hydrargyrum sulphuret and oil of cinnamo also golden hartshorn, that had great reputation as a cordial and sudorific, and was composed of crocus solis
and prepared hartshorn.
The stannate of gold, well known as the purple of The stannate of gold, well known as the purple of
Cassius, was formerly preseribed internally, to be taken Cassius, was formerly prescribed internally, to be taken
in progressive doses of to to 1 grain, from $1 / 2$ to 1 grain
being also recommended to be rubbed over the tongue. The metal itself was ued in the form known as divided
gold, made by forming an amalgam of mercury and gold, made by forming an amalgam of mercury and gold leaf, in parts of one to six, the mercury being
taken up by hot nitric acid, then dried, and the resiDivided gold

Divided gold was administered in doses of $1 / 2$ to 5
grains, daily, by rubbing on the gums. It was used also grans a the sirup of gold, a preparation recommend-
ed in lotions for application to syphilitic ulcers. The formula is given as follows :

R. Divided gold

Simple or gum sirup.

.24 grains.

Mix intimately.

$3 \mathrm{j}$.

The chloride of gold was once frequently ordered

in medicine, and usually given in doses of $\frac{1}{10}$ to 14 pills. Combined with starch it formed the powder
of chloride of gold. The tinctura auri was a someof chloride of gold. The tinct ura auri was a some-
what expensive preparation, and made in the following

R Pure gold..................

Dissolve and add

Set aside until the color of the acid disappears, th

Rectified spirit

$\xi$ viij.

The dose of this tincture was from 5 to 10 drops.
nother form was aurate of ammonia, known as aurum fulwinaris. It was made by precipitating divid-
ed gold from solution in nitro-hydrochloric acid with ed gold from solution in nitro-hydrochloric acid with of from three to six grains. It was used in the prepapart of aurate of ammonia in four parts of oil of
juniper.

\begin{tabular}{c|l} 
A popular rewedy largely used in Continental & for $\$ 12$ per wonth, and in 1850 for $\$ 13$, and in 1861 for \\
countries was known as General La Motte's drops, and & $\$ 15$. The same class of help was hired this season for an
\end{tabular} onsisted of aurate of aumonia dissolved in nitric
average of $\$ 18$ per month. This is an increase of about cid, and diluted with rectified spirit. It was 50 per cent. in the cost of hired help but for 10 years the The bromide of gold has been recently prescribed $\begin{aligned} & \text { better facilities for marketing the same, has more than } \\ & \text { paid the increase. Railroad freights are higher than } \\ & \text { the }\end{aligned}$ Ty several medical men in cases of epilepsy with suc- they ought to be, and farmers justly complain ; but oss. It is given in doses of one-sixteenth to one-tenth potatoes raised on my farm last year brought 20 cent
a bushel more than they would if the canal were the again come into use in medicine, and its preparations
once more on the shelves of the pharmacy.-Pharma-
ceutical Journal.

AGRICULTURAL DEPRESSION.

MR. C. S. RICE, of Lowville, N. Y., writes as follows
the Rural New-Yorker: There are no deserted farms in this vicinity, but many farmers have the spirit of deserters, and are
ready to join in the general cry about the low prices of
dairy products, and the depreciation in value of farming lands. Perhaps it may be well to recall some earwere really better than these. During the war, and for years after its close, high prices prevailed through depreciation in the value of
the paper money when compared with gold, the real civil war, it would be useless to institute a comparison between that period and the present. A state of war roin fts evil effects. In sympathy with the premium on gold, farming lands advanced in price from 50 to 100 to the amount of $\$ 5,000$ suddenly advanced in appar-
ent wealth to $\$ 8,000$ or $\$ 10,000$. Solle sold their farms and retired from business. Others continued farming began a course of more expensive living : n keeping
with what was supposed to be greatly inereased capiwith what was supposed to be greatly increased capicome. Custom has with many all the force of neces sity, and a return to the simpler ways and cheap liv
ing of former times is regarded as an impossibility. Through changes in the currency and competition with brought under cultivation, it cannot be denied that The general wail of farmers over the low price of arm products has accelerated this depreciation and decried theirown property by joining in the declaration bought high priced land several years ago, and it is couraging; but when the re is little or no debt, a family with a homestead farm, fairly well situated, need not
raise the question of value per acre. If the fertility raise the question of value per acre. If the fertility
of the soil has been mainta ined, advance or deprecia-
tion in price is of no great importance to the permaIf the present is compared with a former period, the prices of farm products and the amount of necessary
arm expenses are the principal items relevant to the uarket beyond the limits of the county was made in Low ville. It was made from a dairy of 15 cows and
was kept through the season. In the fall the dairyman learned that his butter and cheese could be sold for
cash in Rojte. 42 miles distant. He accordingly loaded cash in Roure. 42 miles distant. He accordingly loaded
them into his wagon and drew them to that warket, 5 cents per pound. He return ed home so well pleased
and with the result of his venture that he took measures to
ingrease his dairy to 30 cows for the next year. He was for many years a successful dairyman and amassed
quite a respectable fortune in the business. He and quite a respectable fortune in the business. He and labor of their own hands and brains, and, of course, affairs. This fact is mentioned to show that the business of dairying was more promising than any other at
that time. It is evident that if this had not been so, this wideawake man would not have engaged in it. Farmers had tried raising peppermint and distilling
oil from it, but after a considerable amount had been oil from it, but after a considerable amount had been
expended in building stills, and one or two crops had been sold at a fairly remunerative price, it was found
that there was an over-prod uction of oil and the business was soon abandoned. About the time of the in-
troduction of cheese dairying, wool was largely produced here. Large flocks of sheep were kept on nearly all the farms in this vicinity. There was no market
for un utton, and as nearly all the sheep died a natural ath, the only profit derived frow them was from the It is manifest that Mr. Bowen when be drew his first
cheese to Rome and received five cents per pound for it, was engaged in the best paying business of that day. Think of this, ye discouraged dairymen of towagon with the mud in many places a foot deep, was not a very great price; but Levi Bowen, a man of sound sense and marked ability, came home from that
sale with a face radiant with smiles, and telling every one of his good fortune, went to his work with fresh courage and increased energy. From this small be-
ginning cheese dairying soon grew to be the leading industry of the county and has continued to be such
for more than 50 years. Cheese was sold for five cents in 1833 A fair diairy of cheese was delivered at Rome in
the year 1842 for $\$ 1.62$ per $\mathrm{cw}$ t. In 1852 cheese sold for $61 / 2$ cents per pound. At no time previous to $1860 \mathrm{did}$ milk wanufactured into cheese bring better net re-
turns than it did last year. Eighty cents per 100 turns than it did last year. Eighty cents per 100
pounds of milk was about the average price received
by dairy men last year by dairy men last year This is far better than the
average of the 20 years between 1840 and 1860 . Beef was sold from nuy farm last year for a higher price than
was realized at any time before 1860 , and the price of pork was above the average of 20 years previous to
that date. Colts have brought 50 to 100 per cent. more during the last four years than at any time bemarket for potatoes, and they seldom brought more than 20 or 25 cents per bushel in Lewis County. In
1840 a good farm hand could be hired for eiglut months only available method of transportation. Of course this view of the subject is wholly local and limited in
its application; but it is a matter of experience. Hire help is perhaps the only item of necessary expense
that costs more now than before the war. Coffee is higher, but it is not generally regarded as a necessity, and was but little used in former times. It is also true
that whisky is more costly, but I am happy to know hat representative farmers have no use for that

Farwers expend more for implements than formerly
ant tools were never so cheap as at the present time. but tools were never so cheap as at the present time.
The opportunity to purchase and use labor-saving implements and machinery is really a very great advan-
tage enjoyed by the farmer of to-day. If he makes the best possible use of improved tools, and so cares for paid out for tools is a disadvantage to large farmer, perpaid out for tools is a disadvantage to the farmer, ner-
haps he would better go back to the hand scythe, the hand rake and grain cradle, to the hand fork for unloading hay, and the flail for thrashing grain, and give up the use of cultivators, improved harrows, grain In this vicinity well ago.
agriculture 50 years ago

In this vicinity well managed farms are as prod uct-
ve as they ever have been. Prices of ve as they ever have been. Prices of farm products
verage higher than they did for a period of 20 years refore the war. Necessary farm expenses are not
reater than they were then; but family and personal expenses are much larger, and herein is found the s they formerly did. Comfort seems to require that a farm hou seshould be carpeted throughout; $b$ but, afte merly if there were one spare room in the house ani that was carpeted, the requirements of custom were work of the farmer's wife, and involved no cash expense
except for carding the wool and buying coloring mahould wore than mention the costly furbid that I should wore than mention the costly furniture, the sleighs and harnesses that illustrate a class of expenses While it may be neither desirable nor practicable for the young farmer to go back to the frugal habits and mple life of his father, it is the height of folly to let
fashion dictate expenditures of the class above men-
toned beyond what assured income warrants. Enjoyment of life does not necessarily depend on these things. The universal testimony of successful and wealthy fartrict economy is that they enjoyed life as well during and in a farmore expensive way. Farmers. as a class, re quite as well situated to enjoy life as the average of those engaged in other occupations, and their
numbers are such that when perfect combination is numbers are such that when perfect combination is
secured, their rights will be protected and they will be
able to reap the full benefit of their toil. Meanwhile, by attending to his business carefully, by breeding and keeping improved stock, by adopting the best methods
of cultivation, and practicing strict economy, the farmer may retain his home and add something to his capi-
al each year. But the farmer who spends his time houting that "farmin' don't pay," that farms are all shouting that "farmin' don't pay," that farms are all
mortgaged, that farming land is not worth anything,
in short, that agricultural bankruptey is impending ver the whole country, will probably suceeed in making imself quite unhappy and bringing about still further

\section{NOTES FOR CHEESE MAKERS.}

By JAS. W. Robertson, Dairy Commissioner. CHEESE FACTORIES AND THEIR SURROUNDIN

1. The present, not next week, will be the best time the that all the drainage facilities of the factory are 2. Whey runs, spouts and tanks should be put into 3 . If there be a leaking will be prevented.

3 . If there be a leakage anywhere from floors, spouts
or tanks, which is not immediately preventable, provisten should be made at once for the drainage of the apply of lime and gypsum should be spread around
such places. Don't fail to secure a barrel or two of 4. If the factory buildings are not painted and will
a d the ding the hot weather. not be painted, get them whitewashed this month. I ou cannot get that done by the proprietors or mana-
cers, get perwission and do the rest yourself. A whitewashed curing room of imperfect construction can be washed. If the cheese become injured, through excess wash your reputation then, whether the blame belongs 5. Make the surroundings of the factory neat and
6. Plant a few trees and a great many flowers.
6. While keeping the outside of the prewises as 6. While keeping the outside of the premises as
creditable to your taste and neat habits as possible, make the inside to reflect still more your aversion to
everything untidy and dirty. Give every part of the factory a thorough cleaning and keep it in a sweet
state all summer. 7. Before the curing room contains any cheese, fumigate it by burning some sulphur mixed in alcohol.
That will help to prevent the growth of mould on the
outside of the cheese. 8. The leisure hours of May, before the large flow of
milk is received, should be employed putting all the milk is received, should be employed putting all the best of working order.
structed and supported that it will not shake or structed and supported that it will not
vibrate during the coagulation of the milk, 